\title{
DIGITAL COMPETENCE DEVELOPMENT AS STRATEGIC LEARNING
}

\author{
A case of business system implementation with digital \\ competence development
}

Kalle Mäkinen and Ari Alamäki

TietoEnator Oyj, Arabianranta 6, FIN-00560 Helsinki, Finland

\begin{abstract}
This paper reviews a successful digital competence development solution that was used to implement a business system in a large international organization. The following questions are examined: What makes a successful digital competence development case? What issues should digital competence developers consider? What aspects should management stress in corporatewide business system implementation with digital solutions? The pedagogical requisites from the developers' viewpoint and return on investment from management's viewpoint are illustrated. The findings show that return on investment in digital competence development solutions can be reached if development meets business triggers. The findings indicate that if the solution is well designed, it is used creatively in several contexts.
\end{abstract}

Key words: competence development, learning models, business/commerce

\section{INTRODUCTION}

International knowledge-intensive corporations must constantly readjust their internal processes to meet the discontinuous challenges of the competitive landscape. Corporate-wide business systems play a key role in this endeavour (Tuomi, 2003). However, modern business intelligence information systems take us only halfway on the journey towards actual business excellence: business intelligence is intelligence only if it is in use and put to practice across the corporation (Brown \& Duguid, 2000). The codified information in sophisticated business systems evolves into intelligence through effective utilization and concrete practices. What 
follows is that effective competence development strategies that meet the challenges of digital economy are needed. The codified and articulated knowledge must be deployed to intelligence through concrete means.

Change management and knowledge management (Tuomi 1999; 2003) in a knowledge-intensive organisation share a common denominator: how to mobilize the strategic ideals and fads into practice? This article deals with one successful case involving a strategic-driven e-Learning solution that enabled a faster implementation of a new business system. The question this paper strives to answer is what makes a successful digital competence development (DCD) case? Can DCD triumph over the challenges of corporate-wide business system implementation? One of the major reasons why information systems fail is that they neglect actual practice and activity, i.e. how, when, why, and where people, and organizations, learn. Learning is a key issue in the competitive landscape. It is also a key concept that both developers of DCD solutions and management of the organization using the solutions must make explicit and understand. Learning and change go hand in hand, whether unlearning the old or learning new on top of the old practice (e.g. Wenger 2000; Ahonen 2000). For instance, a mistake caused by business process re-engineering was that it forgot practice and people; information systems were seen as a major cost-saving instrument that can be implemented top-down, independent from an organisational context, its phase of development and people (Davenport 1995; Malhotra 2002).

Traditional commodity-based information system delivery can serve well in operations that do not deal with the core processes of an organization. However, information systems for organizations' core processes require deep understanding of what makes the organization tick. A tendency towards close partnership-based models among IT service providers can be seen as an endeavour to provide information technology solutions that fit to context, processes and business - while not forgetting people either. So far only few IT service providers have been able to implement this model successfully showing clear results of the superiority of the model.

A similar approach is needed when dealing with DCD; off-the-shelf eLearning solutions can only deal with generic context-independent and general subjects. The case at hand shows that in implementing a business system that deals with the core processes of an organization, a tailored eLearning solution is needed: the contextual needs of organisational learning and the organization's development phase must first be understood. Only then can DCD endeavours add value. The ability to understand this is essential, both on the supply and demand side of DCD.

The paper first describes the organisational context of the case and then illustrates the pedagogical concept of the solution. Next, empiric findings of 
the case study are illustrated, and finally the cost effectiveness of the solution is scrutinized.

\section{ORGANISATIONAL CONTEXT OF THE CASE}

After years of mergers and acquisitions, the organization incorporated a number of different corporate cultures and ways of working. Its business intelligence was dispersed, tacit, or only partly codified in the old business system. The objective of the proposed e-Learning Solution was to enable faster and more cost-effective training of a new common business system throughout the organization. The learning need was strategic, and it was decided to use digital technologies to fill the gap.

The new business system was ready for implementation throughout the organization; it would replace the older systems. Change management activities were necessary, and users needed to be retrained. A tool that would enable training independent of time and location was essential in this networked organization. Consistency and follow-up of the efficiency of the implementation were required by management. Management needed to asses the actual use and cost-effectiveness of the training solution internationally. Figure 1 illustrates the organisational context, and challenges, that the digital learning solution was created to answer.

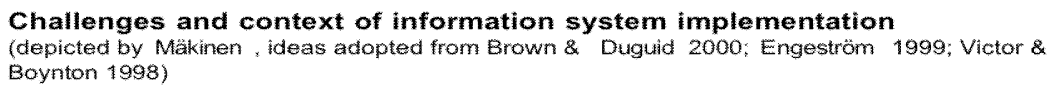

Practice

m varied cultural context of networks of activity,

- social \& informal practices,

- organization deep structure.

cultural \& tacit knowledge

- bottom up

- discontínuous change

- old business systems, historical activity \& tools

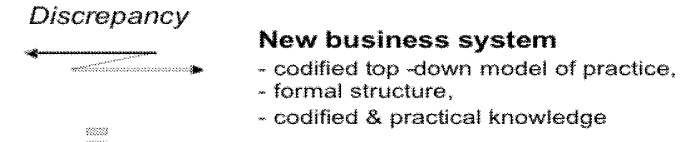

Development challenges of implementation \& harmonization

Learning Solution of the business system

Figure 1. Organizational context of the e-Learning solution.

A traditional training approach was considered too expensive to implement. Moreover, a more scalable solution to fill the competence need was needed. Instead of performing a heavy road show about the new business system, the e-Learning solution enables training in the same place 
where users face the learning need. In addition, a stand-alone solution that would fit into diverse platforms, intranets and content management systems was needed.

\section{PEDAGOGICAL DESCRIPTION OF THE SOLUTION}

Pedagogically sound DCD tools must be used in order to provide answers to organisational strategic needs. Pedagogical concept designers and consultants are needed to keep the development on track. Bloom's (1956) taxonomy can be used to structure types of knowledge and depth of learning. Different DCD approaches (e.g. self-study, blended learning architecture, and computer-supported collaborative work) are positioned in Figure 2 according to the learning needs and objectives they address.

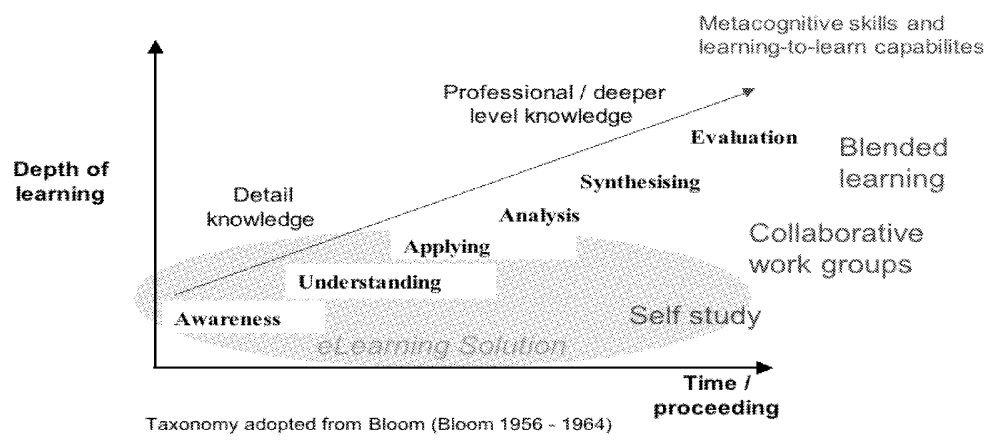

Figure 2. Depth of learning and knowledge of the business system e-Learning solution

The depth of learning of a new business system is three-fold: Firstly, organisational members must become aware of the new business system and understand the additional value that it can bring to their daily business. Secondly, they must understand the codified knowledge in the business system. They must also understand the logic behind using the business system. Thirdly, they must be able to apply to their work what they have learned about the business system. If the depth of learning and level of knowledge are retained only in the level of understanding, the organisational intelligence will be lacking. Applying knowledge brings more value for business purposes and needs. Management in the customer organization and developers of the DCD solution can reap the greatest benefits from the solution if these aspects are addressed in the competence development 
project. We point out that, for instance, blended learning solutions represent the total picture of e-Learning. They can be used for several learning objectives. Training about a common business system can be also deployed using blended learning methods and architecture; however a self-study eLearning solution fulfils also the prior needs of the training. An interesting remark on the DCD case at hand should be made: though it was originally designed for self-study purposes, the quality facilitators used it as a blended learning solution.

\section{EMPIRICAL FINDINGS}

Six end-users (quality managers, project managers) of the e-Learning solution were interviewed for this article. Also, the management team of the organization was interviewed (HR management \& HR development in Finland and USA). The interviews were conducted as structured theme interviews. The same questions were posed to both the users and management. Moreover, the writers of this article have themselves been developers (pedagogical expert, pedagogical concept designer) of the eLearning solution.

Table 1. Interviewed personnel

\begin{tabular}{ll}
\hline Interviewed personnel & Work roles \\
\hline Management team of the organization: & - HR manager (Finland), \\
& - HRD -manager, \\
& - VP development \\
& - HR manager (Subsidiary in USA) \\
\hline End users: & \\
\hline Four users in Finland & - Process developer, \\
& - team leader, \\
& - logistics development manager, \\
& - two project managers \\
\hline One user in Denmark & - Quality facilitator for the business \\
& system rollout \\
\hline Two users in Norway & - Quality facilitator for the business \\
& system rollout \\
\hline
\end{tabular}

The interviews (see Table 2) showed that the e-Learning solution was used more creatively than is usual for a self-study tool. This shows the flexibility and adaptability of e-Learning solutions to fit with varied needs of a given organization. If the solution is strategically and conceptually sound, solution will conform to the organization's phase of development and business triggers. What follows is that the organization applies it creatively. 
Table 2. Excerpts from interviews.

\begin{tabular}{ll}
\hline $\begin{array}{l}\text { Management's illustration for what the } \\
\text { solution should be }\end{array}$ & $\begin{array}{l}\text { End user experiences about what the } \\
\text { solution is and how it was used }\end{array}$ \\
\hline "Training geographically dispersed & "We used it before the roll-out sessions \\
organization's personnel effectively, and & of the new business system." \\
with common solution." & "We gave it to users for orientation \\
"Training new users to use new business & $\begin{array}{l}\text { before any formal training." } \\
\text { system version." }\end{array}$ \\
"Training old users to use new business & $\begin{array}{l}\text { "I have used it sometimes after the } \\
\text { orientation when I need to refresh my } \\
\text { memory about it." }\end{array}$ \\
$\begin{array}{ll}\text { system version." } & \\
\text { "Lead users to learn in a self directed } & \\
\text { manner." } & \\
\text { "Enable continuous and repeatable } \\
\text { training and implementation process." }\end{array}$ \\
\hline
\end{tabular}

\section{DIGITAL COMPETENCE DEVELOPMENT COST EFFECTIVENESS}

The debate on measuring learning and its cost-effectiveness approaches that of measuring intangible assets (Sveiby 1997). We present three factors that affect the cost effectiveness of digital competence development. If these factors are met, the cost-savings and return on investment (ROI) can be significant per enrolled student/person.

- The e-Learning solution can be studied by sections; the estimated time is two hours and in classroom training. the estimated time is three hours. More time is spent when transportation costs to the venue are calculated. Major timesavings can be achieved.

- When the trainers and other personnel travel to several locations, costs can rise significantly if the implementation is ongoing and new personnel must be trained continuously.

- Using a classroom does not guarantee good learning results; evaluation of what was learned, and the transfer of learning, may be problematic.

DCD solutions can be used whenever they fit into a user's timetable and whenever the learning need arises. Keeping the third factor in mind, together with measuring learning results compared to traditional classroom training, can bring cost-savings. The use of classroom sessions is difficult to measure, costs too much, or takes too long, whereas the user report function does it automatically. The user reporting, ROI (and its measurement) deserve more thorough examination. 


\section{DISCUSSION}

In the introduction we asked 'what makes a successful DCD case?'. 'Can DCD triumph over the challenges of corporate-wide business system implementation?' We conclude this paper with four remarks on these questions:

- Business system implementation is an ongoing process that a DCD program can support and expedite. It goes hand in hand with wider organisational processes and change management activities. The accumulative data from the reporting function of the system shows that the e-Learning solution is in continuous active use. An interview with a US-based subsidiary revealed that the e-Learning solution could be used to meet their local needs; it serves as a strategic tool to HR management and for quality management.

- An e-Learning Solution can only reach its objectives if they are well conceptualised and designed, taking into account strategic organisational learning needs. The e-Learning solution was created in a need-push situation (Fleck 2002); the organization had a clearly defined strategic need for an e-Learning solution. The e-Learning designing process proceeds iteratively, as does any development process. A customer need must be formulated into concrete means, actions and solutions. eLearning can also create demand pull. A reporting function can be used to anticipate such aspects.

- The multifaceted aspects of organisational learning should be considered, e-Learning being one important aspect. However, its connection with other organisational learning aspects is systemic; e-Learning can support, enhance or exploit both informal or emergent and complex learning in an organization (Stacey 2001). It can be used as an operational instrument in meeting clearly defined management needs.

- There can be a significant return on investment if the number of users exceeds economies of scale and geographical dispersion is wide. eLearning solutions can be used for mass training purposes, ongoing orientation procedures, and as part of traditional classroom sessions.

Complex and creative organisational realities and practices ultimately define how the DCD solutions are actually used. Future research should examine an organization's maturity and dynamic capabilities in relation to the use of DCD solutions.

In conclusion, managerial strategies must align with the pedagogical concepts of the digital competence consultants in order for strategic learning experiences to occur through DCD means. 


\section{REFERENCES}

Anderson, L., \& Krathwohl, D. R. (2001). A taxonomy for learning, teaching and assessing: A revision of bloom's taxonomy of educational objectives. New York: Longman.

Bloom, B. S. (Ed.) (1956). Taxonomy of Educational Objectives. New York: David McKay Company Inc,.

Brown, J. S., \& Duguid, P. (2000). The Social Life of Information. Boston: Harvard Business School Press.

Davenport, T. H. (1995). The fad that forgot people. Fast Company, 1(November).

Engeström, Y. (1987). Learning by expanding. Helsinki: Orienta-konsultit.

Engeström, Y., Engeström R., \& Vähäaho T. (1999). When the centre does not hold: The importance of knotworking. In S. Chaikli, M. Hedegaard, \& U. Jensen, (Eds.), Activity theory and social practice: Cultural historical approaches. Denmark: Aarhus University.

Fleck, J. (2002). The structure of technological evolutions: Linear models, configurations, and systems of development. Paper presented to Nobel Symposium on Science and Industry in the 20th Century, Stockholm 21-23 November.

Victor, B., \& Boynton, A. C. (1998). Invented here: Maximizing your organisation's internal growth and profitability. Boston: Harvard Business School Press.

Lave, J., \& Wenger E. (1991). Situated learning: legitimate peripheral participation. New York: Cambridge University Press.

Malhotra, Y. (2002). Why Knowledge Management Systems Fail. In C. W. Holsapple (Ed.), Handbook on Knowledge Management. Heidelberg, Springer-Verlag.

Nonaka, I., \& Takeuchi, H. (1995). The knowledge creating company: How the Japanese companies create the dynamics of innovation. New York: Oxford University Press.

Senge, P. (1990) The Fifth Discipline: The art and practice of the learning organisation. New York: Doubleday.

Stacey, R. D. (2001). Complex Responsive Processes in Organisations: Learning and Knowledge Creation. New York: Routledge.

Sveiby, K. E., (1997). The New Organisational Wealth, Managing and Measuring Knowledge-Based Assets. San Fransisco: Berrett-Koehler

Tuomi, I. (1999). Corporate knowledge. Theory and practice of intelligent organisations. Helsinki: Hakapaino.

Tuomi, I. (2003). The future of knowledge management. Lifelong Learning in Europe, 7(2), 69-79.

Wenger, E., \& Snyder, W. M. (2000). Communities of practice: Learning, meaning and identity. Cambridge: Cambridge University Press.

\section{BIOGRAPHY}

Kalle Mäkinen (M.Ed.) is a pedagogical concept designer in TietoEnator's e-Learning solution unit. $\mathrm{He}$ is undertaking a $\mathrm{PhD}$ about corporate strategy \& knowledge management. His research interests are organisational learning, partnerships, networked/extended enterprise, boundary crossing, collaborative learning and knowledge management. 